Abant Tıp Dergisi

\section{Derleme / Cilt 10 Sayı 1 Yıl 2021}

Abant Medical Journal

Review / Volume 10 Issue 1 Year 2021

\title{
Postoperatif Üriner Retansiyonda Risk Faktörleri
}

Risk Factors for Postoperative Urinary Retention

Züleyha ŞiMŞEK YABAN ${ }^{1}$ (D), Süreyya KARAÖZ2 (D)

${ }^{1}$ Kocaeli University Faculty of Health Sciences Surgical Nursing Department, Kocaeli, Turkey

${ }^{2}$ Istanbul Bilgi University Faculty of Health Sciences, Nursing Department Dolapdere Campus, Istanbul, Turkey

\section{Öz}

Üriner retansiyon hastanın rahatsızlığını arttırmanın yanı sıra, aşırı genişleme ile mesaneye zarar verebilir ve kronik nefropatiye, sepsise, mesane duvarının atonisine ve üriner sistem enfeksiyonu gelişmesine neden olabilir. Bunların yanı sıra hastanede kalma süresinin uzamasına hastaneye tekrarlı yatışlara neden olabilir ve yaşam kalitesini olumsuz etkiler.

Postoperatif üriner retansiyon gelişiminde birçok faktör rol oynamaktadır. Postoperatif üriner retansiyon gelişmesinde etkili olan risk faktörlerini; hastaya, ameliyat ve anesteziye ait çeşitli faktörler ve perioperatif süreçte kullanılan ilaçlar olarak gruplandırabiliriz. Sağlık ekibinin tüm üyeleri bu risk faktörlerinin bazılarına müdahale edebilirken, yaş, cinsiyet, hastada var olan hastalıklar gibi değiştirilemeyen risk faktörlerine müdahale edemezler. Bu nedenle sağlık ekibinin hastada var olan risk faktörlerinin farkında olması çok önemlidir. Postoperatif üriner retansiyonun önlenmesi ve yönetimi ekip üyelerinin iş birliği ile daha mümkündür. Bu çalışma postoperatif üriner retansiyonda risk faktörlerini değerlendirmek amacıyla hazırlanmıştır.

Anahtar Kelimeler: Postoperatif komplikasyon, idrar retansiyonu, risk faktörleri, hemşirelik

\section{INTRODUCTION}

There is no consensus made on the definition of surgical complication; however, Zeitz et al. (1) have defined the post-operative complications term as "changes occurred in the physiological condition of the patient during the postoperative recovery period". These changes (complications) have involved serious changes requiring medical and nursing interventions (bleeding, respiratory problems, wound separation, etc.), changes predicted to be

\section{Abstract}

In addition to increasing the discomfort of the patient, urinary retention may harm bladder with extreme expansion and it may cause to develop chronic nephropathy, sepsis, atony in the bladder walls. All of these might increase the time the patient spent in the hospital, lead to repeated lying in hospital and negatively affect the quality of life. There are various risk factors that play a role in the development of postoperative urinary retention. We can classify the risk factors which are effective in the development of postoperative urinary retention such as; patient, operation and anesthesia related various factors and the medicines utilized in the perioperative period. All disciplines on the health team can intervene in some of these risks whereas, they cannot intervene the other risks such as age, gender, preexisting diseases since these risks cannot be changed. However, it is very important for the health team to be aware of the risk factors in the patient. Prevention and management of postoperative urinary retention is more possible with the cooperation of team members. This study is prepared in order to evaluate the risk factors of postoperative urinary retention.

Keywords: Postoperative complication, urinary retention, risk factors, nursing

frequently experienced by patients after surgery (pain, nausea-vomiting, etc.), and changes that are not life-threatening and can be eliminated with only nursing interventions (wound leakage, syncope, gas, etc.). Urinary retention is one of the estimated postoperative complications. The American Medical Association has defined the urinary retention as "the most common complication seen in the first 2-4 hours after surgery" (2). Patients are normally expected to urinate in at least 12 hours after surgery. However, some patients are not able to urinate 
in this period even they need to do. In addition, some patients do not feel the urine accumulation due to blackout, sacral plexus block or injury, thus the bladder is filled with urine and stretched. When the urine exceeds $500 \mathrm{~mL}$, urine retention occurs since the bladder can not contract and be drained (3).

Urinary retention is a problem that is commonly seen after anesthesia and surgical intervention. The lack of a universal definition of urinary retention and the differences in the diagnostic criteria significantly complicate the diagnosis of postoperative urinary retention (POUR). The common definition of POUR is the impairment of the bladder drainage with the increase in the urine volume, and the inability to urinate despite the need to urinate with a full bladder $(3,4,5)$. Since there is no consensus on the definition of POUR, there are a large number of factors in its etiology, and there is a lack of general diagnosis criteria (6), its prevalence varies between $5 \%$ $75 \%$ of all surgical procedures. Urologic, orthopedic, colorectal procedures are known to carry high risk for POUR. The estimated incidence of POUR is approximately $27 \%$ after hip and knee arthroplasty and $39.4 \%$ in the neurosurgical population. (7-9).

\section{MATERIALS and METHODS}

The study was conducted as a retrospective screening of publications evaluating risk factors of postoperative urinary retention between 2000 and 2020. For this purpose, a scan was performed using the keywords "urinary retention", "postoperative urinary retention" and "risk factors for postoperative urinary retention" over the Internet access network of A University. Pubmed, OVID-LWW, Scopus, Science Direct, EBSCHO, Complete Medline, the Cochrane Library, national central thesis and ULAKBIM databases were scanned. The criterias for inclusion by the researcher in the study were determined as published between 2000 and 2020, written in Turkish or English. In this study, all sources including boks, original articles and reviews were used to determine risk factors for postoperative urinary retention. In this study, 41 references were included; 36 of the them were an original article/literature review which had published in a journal, 4 of them were from a published book and only one was a poster.

\section{FINDINGS}

When the current literatüre is examined, it is being considered that several factors have a role in the etiology of POUR. The main factors may be expressed as the filling of urinary bladder with a high amount of fluid applied in order to prevent hypotension, during the perioperative (preoperative, intraoperative and postoperative) period. Prevention of perineal relaxation because of the pain makes urination difficult. The pharmacologic agents used in the intraoperative and postoperative period cause the urinary bladder functions to be disturbed by affecting the detrusor muscle, sphincter muscles and related neural cells. Urinary bladder contraction and cortical stimulation is suppressed due to analgesics applied after the operation and urination urge does not occur. The urinary bladder stretch more than its physiologic limits and in time, decomposition occurs in detrusor muscle. The elasticity and urination reflex of bladder then disappears for a time. The disturbance of bladder function for a period, due to the decreased feeling of bladder decrease of detrusor contractility or both of them may cause some difficulties in urination after the operation (10). The anxiety or emotional stress experienced because of the operation may cause a need for urination or an increase in the frequency of urination. Emotional stress complicates the relaxation of abdominal and perineal muscles. If the individual is not relaxed, outer urethral sphincters may not relax, urination cannot be completed and an amount of urine may stay in the bladder, urination urge may be felt again. Secreting a high amount of ADH (antidiuretic hormone) from hypophysis due to the operation 
stress may cause to a decrease in the aldosterone level and therefore, the amount of urine may be decreased. Anesthetics and narcotic analgesics decrease the speed of glomerular filtration and thereby the urine amount. Moreover the bladder prevents the sensual and motor impulses between the spinal cord and the brain. The patients in the postoperative period often cannot feel their bladder to be full and they cannot urinate or they have urinary incontinence. Urinary retention develops in the patients (11).
Patient related factors, various factors associated with the operation and anesthesia, and medicines used in the perioperative period are effective in the development of POUR (Table 1). Health team can intervene in some of these risks whereas, they cannot intervene the other risks such as age, gender, preexisting diseases since these risks cannot be changed. Some of them are the responsibility of other team members, too. However, it is very important for the nurses to be aware of the risk factors in the patient. The factors which lead to the development of POUR in the patient are discussed as follows:

Table 1. The Risk Factors for Postoperative Urinary Retention (POUR)

\begin{tabular}{lll}
\hline Patient Related Factors & $\begin{array}{l}\text { Operation and Anesthesia } \\
\text { Related Factors }\end{array}$ & $\begin{array}{l}\text { Utilized Medicines in The } \\
\text { Perioperative Period }\end{array}$ \\
\hline -Age & -Type and duration of operation & -Anticholinergics (oxybutynin, \\
& & tolterodine, atropine) \\
-Sexuality & -Given liquid amount in the & -Antiarrhythmics \\
& postoperative period & \\
-Body Mass Index (BMI) & -Type and duration of anesthesia & -Opioids \\
-Usage of cigarettes and alcohol & -Operation and anesthesia related & -Antipsychotics \\
-Medical record of the patient & factors & -Antiparkinsons \\
*Diabetes Mellitus $($ DM) & & \\
*Existence of a urinary problem & & \\
-POUR experience & & -Sympathomimetics \\
-Anxiety & & -Beta blockers \\
-Constipation & & -Antihistaminics \\
-Increase in serum creatinin values & & \\
\hline
\end{tabular}

\section{Patient Related Factors}

\subsection{Age}

Having an age above 50 is a determining factor in the development of POUR. While Khori et al. (12) states that having an age above 55 causes a high risk in terms of POUR development, different studies states higher POUR development risks for patients above 60 when compared with young people (7). The weakening of the bladder muscles due to old age may prevent the bladder to contract strong enough and thus it may cause the bladder not to be emptied completely. Moreover, the neuronal degeneration due to old age may create pathological changes peculiar to functional disorders and may cause to urinary retention (13). It is stated in a study that there is a meaningful correlation between the 
development of POUR and age. This study expresses $34.5 \%$ POUR development rate above the age of 50, $20.7 \%$ POUR development rate between the age of 31 and 50 and $9.1 \%$ POUR development rate between the age of 18 and 30 (14). Although there are different cut-off points in ages and there is no consensus between the results of different studies, it is possible to say that having an age above 50 causes a risk in terms of the development of POUR.

\subsection{Sexuality}

It is pointed out in the studies that, men have a higher risk for the development of POUR (15). There are some differences between the sexualities in terms of POUR development. Women have problems, because they are having difficulties in urinating into duck sliders. The urination becomes harder while lying in supine position for a woman. Remaining stationary for a long time due to infusion of intravenous (IV) liquids and being unwilling to urinate due to privacy are other factors. Men have problems because, they feel more comfortable while they urinate by themselves and they refrain from applying urinary catheter since they think it would be painful, they are having more problems while urinating in bed, their urinary system anatomy is different, they are more prone to urinary retention owing to having sexuality dependent pathologies like Benign Prostatic Hyperplasia (BPH) $(7,12,13,16)$. In this context, identification and catheterization are suggested especially for older male patients before an operation (17).

\subsection{Diseaes the Patient Has}

All the illnesses that disables the fullness sense of the bladder causes control losses in sphincter and prevents the flow of urine and they contribute to the development of POUR. The neurological disorders (stroke, poliomyelitis, cerebral palsy, multiple sclerosis, spinal lesion), diabetics and alcoholic neuropathy, pelvic organ prolapsuses such as cystocele and rectocele in women, BPH in men, urethral stricture and occlusion due to urinary calculus both in men and women, chronic urinary system infection (USI) are accepted as factors that contributes to the development of POUR (18).

\section{*Diabetes Mellitus (DM)}

Bladder dysfunction due to autonomous neuropathy is more frequent in patients having diabetics. DM, which is known for decreasing the sensation, capacity and contractility of urination, increases the number of POUR incidences. By controlling DM better, it is possible to decrease the incidence of POUR $(7,13,16,19,20)$. Identification and catheterization are suggested before an operation especially for older patients having DM (17). It is emphasized that while hypertension in a patient increases the POUR development risk by 1.3, DM increases the risk by $2(21)$.

\section{*Existence of a Urinary Problem and Creatinin Level}

Having urinary system problems (urination difficulty, frequent urination, urinating at night, insufficient urine movement) in a patient before hospitalization is an independent risk factor in POUR development. Thus, evaluating the urinary system functions of the patient before an operation may be effective against the development of POUR (13). Identification and catheterization are suggested before an operation for older patients having BPH (17).

Medical literature is inadequate in explaining the effects of renal medical history and creatinin levels, which are frequently pointed out risk factors in the development of POUR. By adding the risk of men having high incidences in the development of POUR to these two factors, identification and catheterization are suggested before an operation for risky patients in terms of POUR development. By following this protocol and by catheterization of men, which have not only renal disorders but high creatinin levels, the 
POUR development incidence may be decreased $80 \%$. Moreover, it is emphasized that following this protocol may cause only $2 \%$ of the patients to have an unnecessary catheterization (22).

\subsection{Usage of Cigarettes and Alcohol}

Although the usage of cigarettes is found to be related with the development of illnesses or complications, there is only one study which claims smoking to have a limiting effect on the number of POUR incidences when associated with the development of POUR (16). However, in the majority of the studies, the usage of cigarettes (23) and alcohol are expressed as predisposing factors in the development of POUR (24).

\subsection{Body Mass Index (BMI)}

While in some studies it is emphasized that BMI has no relation with the development of POUR $(7,16,25)$; in a study it is stated that low BMI has a role in increasing the urination time after the operation (26). Moreover, in another study it is said that having a BMI higher than $35 \mathrm{~kg} / \mathrm{m} 2$ constitutes an important risk in the development of POUR. This situation is expressed as, having more urinary system disorders and neuropathy related health problems which cause occlusion in patients with high BMI values and using excessive amount of anesthetic agents (27).

\subsection{POUR Experience}

It is stated that a patient who experienced POUR before has a higher risk for urinary retention provided that he has another operation. A positive relation between having a POUR experience history and POUR development has been found in a study, where urinary retention is developed in $19.7 \%$ of the patients that underwent a TKP (total knee prosthesis) operation. It is suggested that these patients to be closely monitored after the operation (28).

\subsection{Anxiety}

Experienced anxiety makes difficult relaxing of perineal and abdominal muscles. If the patient is not relaxed, external urethral sphincter can not fully relax, urination is incomplete and urine remains in the bladder (11).

\subsection{Constipation}

Constipation and fecal impaction might pressure on bladder neck and urethra due to anatomical neighborhood, which might cause narrowing in urethra and prevent urine flow $(18,24)$.

\section{Factors Belonging to Operation and Anesthesia}

\subsection{Type and Duration of Operation}

Operation type is one of the important risk factors in the development of POUR. POUR is most prevalently developed after pelvis and pelvic organ operations. These operations might disturb urination due to local trauma in the neighboring tissues. Edema and inflammation during the recovery period might prevent the flow of urine from bladder to urethra, either by preventing pelvic and sphincter muscles to relax or by giving discomfort during urination (11). While anorectal surgery decreases the parasympathetic conduction to the detrusor muscle, the pain increases the sympathetic stimulation to the urethral sphincter and both of them cause to spasm (29).

Besides pelvic organ operations, POUR incidences show alterations. POUR incidence is stated as $5 \%$ after general surgery operations (6), $7.3 \%$ in patients who underwent a hysterectomy operation (30), $23.3 \%$ in lower joint operations (31), $28.8 \%$ in orthopedic operations (14), 32.2\% after hemorrhoidectomy (32), $36.4 \%$ in plastic surgery operations (14) and $39.8 \%$ after brain surgery operations (7). It is possible to say that patients being old, the amount of intravenous liquid given to the patients being high because of the long operation periods, existence of accompanying chronic illnesses, high doses of 
opioid and anesthetic medicine usage and most importantly diagnosis criteria of POUR are effective in this situation.

Extension of the operation period, which starts with the incision of the patient to be operated and finishes with bandaging the operation location, increases the probability of the development of POUR $(6,33)$. For one day surgery patients, surgery attempts being shorter ensures bladder distension incidence to be low. The development of urinary retention increases dramatically by giving more liquid and administering high dose opioid medicines in operations with longer periods (34). It is stated that the POUR development incidence will increase $11 \%$ for every 10 minutes and $66 \%$ for every hour increments (27). In studies where the relation of operation period with POUR is compared, 12 minutes being the lower limit $(<12$ $\min ,>12 \mathrm{~min}$ ) (13), different time periods ( $\geq 45$ min) (6), (>120 min) (35), (>200 min) (7) in different studies might be taken as reference and found to be related with POUR development.

\subsection{Given Liquid Amount in the Postoperative Period}

Giving excessive amount of liquid might lead to urinary retention by creating a tension in the bladder wall. When the bladder gets filled by urine fully, its contractibility increases since it consists of smooth muscles. However, since an excessively tensioned bladder cannot contract adequately it cannot empty itself. Studies show that giving over $750 \mathrm{~mL}$ (6) or $1000 \mathrm{~mL}$ (36) liquid in operations increase the risk of POUR.

\subsection{Type and Duration of Anesthesia}

The extension of the duration of the anesthesia, which starts by the first intervention and ends with the delivery of the patient to the personnel in waiting room, increases the probability of the development of POUR $(6,33)$. Anesthesia fills the bladder more than normal before the sensation of the urination by suppressing the neural system and prevents voluntary urination (37). While anesthetic agents suppressing the miction reflex by decreasing the intravesical pressure, some parasympatholytic medicines causes urethral resistance by increasing the capacity and decreasing the contraction of the bladder (38). Anesthetics and narcotic analgesics decrease micturition by decreasing the glomerular filtration speed. Furthermore, they prevent the sensory and motor impulses between bladder, spinal cord and brain. The patients who came off anesthesia and deep analgesia usually cannot feel the fullness of their bladder, cannot urinate or hold their urine (11).

The parasympathetic stimulation of the bladder is realized by S2-S4 pelvic neurons, which provides detrusor contraction and relaxation of the cervix vesicae and by pudendal neurons that stimulates the outer sphincter of the bladder. The sympathetic stimulation which exits between $\mathrm{T} 10$ and $\mathrm{L} 2$ of the spinal cord has an effect of inhibiting cervix vesicae. While contraction of the sensory receptors on the bladder wall increases the parasympathetic stimulation, it decreases the sympathetic stimulation that enables miction. Detrusor contraction disappears 2-5 minutes later than the spinal anesthesia injection, and the urination ability returns back depending on the time of the sensory block (S2-S3) to come out on top of the sacral division (34).

Spinal anesthetics create urinary retention risk by causing disabilities on sensing the urination need, bladder and sphincter responses (11). The situation of being not able to urinate due to urinary retention after an operation is observed more in patients who get spinal anesthesia compared with the patients who get general anesthesia (34). Giving excessive amount of liquid during spinal anesthesia, which disturbs the urination sensation and suppress the urination reflex, might contract the bladder excessively and might cause irreversible damages (13). Owing to this reason, the 
excessive amount of liquid which is given to the patients in order to accelerate the evacuation of the anesthetics might be limited.

While spinal and epidural anesthesia cause the development of POUR by preventing the communication of afferent and efferent neural impulses to the bladder, general anesthesia do this by causing bladder atony $(24,32,35)$. In a study which consists of different types of anesthesia, POUR is developed in $16 \%$ of the operations where $70 \%$ of the operations are done by general anesthesia. On the other hand, POUR is develop in almost all of the operations (26\%) where $30 \%$ of the operations are done by spinal or epidural block (8). It is expressed that, the spinal anesthesia in THP (total hip prosthesis) and TKP (total knee prosthesis) operations is a risk factor for POUR and it increases the urinary catheterization risk by $50 \%$ during the postoperative period compared with general anesthesia (39). Although the literature expresses the development of POUR mostly after spinal or epidural anesthesia, it is stated that general anesthesia creates more risk in a study where inguinal hernia restoration is done. The same study suggests doing this operation under regional or local anesthesia (40).

\section{Utilized Medicines in the Perioperative Period}

While anesthesia have general effects such as providing sedation, the medicines which are given in the perioperative period affects the miction reflex by decreasing the fullness sensation of bladder in the postoperative period. The pharmacological agents which are administered in the postoperative period and are the cause of POUR development in majority are anticholinergics (oxybutynin, tolterodine, atropine), antiarrhythmics, antipsychotics, antiparkinsons, sympathomimetics, beta blockers and antihistaminic. These medicines demonstrate similar effects and cause the development of POUR by relaxing the bladder detrusor muscle and by contracting the cervix vesicae (6).

The smooth muscles of bladder and urethra include cholinergic receptors. The cholinergic medicines such as atropine, which is utilized in eliminating the vagal effects such as bradycardia, hypotension and arrhythmias that arises during the operation, cause hypotony by preventing detrusor contraction and obstruct urine making $(6,41)$. Opiate analgesics and antispasmodics decrease the parasympathetic tonus by decreasing the tonus of the detrusor in the bladder and by enabling passive filling (41). On the other hand, narcotic analgesics lead to POUR by relaxing the detrusor muscle, increasing the sphincter tonus and by decreasing the fullness sensation of the bladder (33).

\section{CONCLUSION}

Health staff has important responsibilities in the maintenance of all patient functions, including urine discharge. Especially nurses are expected to fulfill these responsibilities with a systematical approach and in cooperation with team members (physicians, anesthetists, etc.). Such an approach is very important in shortening the duration of hospitalization, increasing the patient's comfort/satisfaction, preventing complications, avoiding unnecessary painful interventions, and improving quality of life.

Prevention and management of POUR is more possible with the cooperation of team members. When the health team recognizes the factors that may be a possible risk for POUR in the patient, the nurse can early identify the patients who have a potential to develop POUR, prevent the POUR development with necessary followups and interventions, and solve the problem with less discomfort when POUR develops. For this reason, it is highly important for the health staff to know the risk factors affecting the POUR development and symptoms, consider that there is a potential to develop POUR in every patient to be undergone surgery and take necessary precautions from the time that patient is 
admitted to the clinic (ensuring urination before going to operation room, hot application after surgery, fluid restriction, etc.), and apply interventions in order to prevent POUR and be able to treat when it develops.

Limitations of this study: The lack of a certain definition of postoperative urinary retention and the differences in the diagnostic criteria significantly complicate the diagnosis of POUR. The common definition of POUR is the impairment of the bladder drainage with the increase in the urine volume, and the inability to urinate despite the need to urinate with a full bladder. However some researchers focuse on urine volume in the bladder. There are different cut-off points related to bladder urine volume. While some researchers define $300 \mathrm{ml}$ and over as a urine volume indicating PUR in the postoperative period, some studies define this as $\geq 400 \mathrm{ml}$, while others set the mark at $\geq 500 \mathrm{ml}$ and some even apply $\geq 600 \mathrm{ml}$ in their definitions. Since there is no consensus on the definition of POUR, there are a large number of factors in its etiology, and there is a lack of general diagnosis criteria, its prevalence varies after surgery.

Informed Consent: Written consent was obtained from the participants.

Conflict of Interest: Authors declared no conflict of interest.

Financial Disclosure: Authors declared no financial support.

\section{REFERENCES}

1. Zeitz K, Mc Cutcheon H, Albrecht A. Postoperative Complications in The First 24 Hours: A General Surgery Audit. J Adv Nurs 2004; 46(6): 633-40.

2. Palese A, Buchini S, Deroma L, Barbone F. The Effectiveness of The Ultrasound Bladder Scanner in Reducing Urinary Tract Infectons: A Meta-Analysis. J Clin Nurs 2010; 19: 2970-79.

3. Güngel H. Postoperatif Bakım ve Komplikasyonlar. İçinde Genel Cerrahi Cilt-I. İstanbul Üniversitesi Tıp Fakültesi Temel ve Klinik Bilimler Ders Kitapları (Ed G Kalaycı): 28-9. İstanbul, Nobel Tıp Kitapevleri, 2002.

4. Geller EJ. Prevention and Management of Postoperative Urinary Retention After Urogynecologic
Surgery. Int J Womens Health 2014; 6: 829-38.

5. Agrawal K, Majhi S, Garg R. Post-operative Urinary Retention: Review of Literature. World J Anesthesiol 2019; 8(1): 1-12.

6. Dreijer B, Moller MH, Bartholdy J. Post-operative Urinary Retention in a General Surgical Population. Eur J Anaesthesiol 2011; 28 (3): 190-4.

7. Alsaidi M, Guanio J, Basheer A, Schultz L, Abdulhak M, Nerenz $D$, et al. The Incidence and Risk Factors For Postoperative Urinary Retention in Neurosurgical Patients. Surg Neurol Int 2013; 4 (61):1-6.

8. Warner AJ, Philips S, Riske K, Haubert M, Lash N. Postoperative Bladder Distension: Measurement With Bladder Ultrasonography. J Perianesth Nurs 2000; 15 (1): 20-5.

9. Choo MS, Lee SH, Lee YG, Chang JD, Han JH. Clinical Factors Influencing Postoperative Urinary Retention After Lower Limb Arthroplasty. Int J Clin Exp Med 2017;10(4):7105-10.

10. Baldini G, Bagry H, Aprikian A, Carli F. Postoperative Urinary Retention: Anesthetic and Perioperative Considerations. Anesthesiology 2009; 110:1139- 57.

11. Süzen LB. Üriner Sistem ve Uygulamaları. İçinde Sağlık Alanında Temel Kavramlar ve Beceriler (Ay FA.): 60910. İstanbul, Nobel Tıp Kitabevleri, 2011.

12. Khori F, Mayyas E, Haddad F, Sbaihat A, Haddad R, Ajlouni M. Evaluation of Post operative Urinary Bladder Distention at Prince Rashid Military Hospital. JRMS 2013; 20(2): 16-9.

13. Toyonaga $T$, Matsushima $M$, Sogawa $N$, Jiang SF, Matsumura N, Shimojima $Y$, et al. Postoperative Urinary Retention After Surgery for Benign Anorectal Disease: Potential Risk Factors and Strategy for Prevention. Int J Colorectal Dis 2006; 21(7): 676-82.

14. Olsen SW, Nielsen J. A Study Into Postoperative Urine Retention in The Recovery Ward. BJARN 2007; 8(4): 91 5.

15. Lingaraj K, Ruben M, Chan YH, Das De S. Identification of Risk Factors For Urinary Retention Following Total Knee Arthroplasty: A Singapore Hospital Experience. Singapore Med J 2007; 48 (3): 213-6.

16. Gandhi SD, Patel SA, Maltenfort M, Anderson DG, Vaccaro AR, Albert TJ, et al. Patient and Surgical Factors Associated With Postoperative Urinary Retention After Lumbar Spine Surgery. SPINE 2014; 39(22): 1905-9.

17. Jung HJ, Park JB, Kong CG, Kim YY, Park JJ, Kim JB. Postoperative Urinary Retention Following Anterior Cervical Spine Surgery for Degenerative Cervical Disc Diseases. Clin Orthop Surg 2013; 5(2): 134- 7.

18. Selius B, Subedi R. Urinary Retention in Adults: Diagnosis and Initial Management. Am Fam Physician 2008; 77 (5): 643-50.

19. Sung KH, Lee KM, Chung CY, Kwon SS, Lee SY, Ban YS, et al. What Are The Risk Factors Associated With Urinary Retention After Orthopaedic Surgery? Biomed 
Res Int 2015; 1-5.

20. Boitano LT, DeBano M, Tanious A, lannuzzi JC, Clouse $D$, Eagleton MJ, et al. Incidence of and Risk Factors for Postoperative Urinary Retention in Men After Carotid Endarterectomy. J Vasc Surg 2020; 72(3): 943-50

21. Çakmak M, Yıldız M, Akarken I, Karaman Y, Çakmak Ö. Risk Factors for Postoperative Urinary Retention in Surgical Population: A Prospective Cohort Study. J Urol Surg 2020; 7(2): 144-8.

22. Dutta S. Postoperative Urinary Retention in Elective Total Hip and Knee Replacement Surgery. Br J Med Res 2008; 1(2): 28-32.

23. Tischler EH, Restrepo C, Oh J, Maltenfort M, Parvizi J. Postoperative Urinary Retention (POUR): What Are The Risk Factors?". Rothman Institute Conference Posters. Paper 8, 2014.

24. Johnson $\mathrm{CB}$, Conner LBG. Practice Points: Postoperative Urinary Retention (POUR). NAON 2010; 1-8.

25. Lawrie $\mathrm{CM}$, Ong $\mathrm{AC}$, Hernandez $\mathrm{VH}$, Rosas S, Post ZD, Orozco FR. Incidence and Risk Factors For Postoperative Urinary Retention in Total Hip Arthroplasty Performed Under Spinal Anesthesia. J Arthroplasty 2017; 32(12): 3748-51.

26. Sokol Al, Jelovsek JI, Walters MD, Paraiso MF, Barber $\mathrm{MD}$. Incidence and Predictors of Prolonged Urinary Retention After TVT with and Without Concurrent Prolapse Surgery. Am J Obstet Gynecol 2005; 192: 1537-43.

27. Hudak KE, Frelich MJ, Rettenmaier CR, Xiang Q, Wallace JR, Kastenmeier AS, et al. Surgery Duration Predicts Urinary Retention After Inguinal Herniorrhaphy: A Single Institution Review. Surg Endosc 2015, 5p.

28. Kumar P, Mannan K, Chowdhury AM, Kong KC, Pati J. Urinary Retention and The Role of Indwelling Catheterization Following Total Knee Arthroplasty. Int Braz J Urol 2006; 32 (1): 31-4.

29. Erbil Y, Değerli Ü. Cerrahide Komplikasyonlar, Ankara, Güneş Kitapevi, 2008.

30. Smorgick N, Delancey J, Patzkowsky K, Advincula A, Song A, As-Sanie S. Risk Factors for Postoperative Urinary Retention After Laparoscopic and Robotic Hysterectomy for Benign Indications. Obstet Gynecol 2012; 120: 581-6.

31. Kreutziger J, Frankenberger B, Luger TJ, Richard S, Zbinden S. Urinary Retention After Spinal Anesthesia With Hyperbaric Prilocaine $2 \%$ in an Ambulatory Setting. BJA 2010; 104(5): 582-6.

32. Lin YH, Liu KW, Chen HP. Haemorrhoidectomy: Prevalance and Risk Factors of Urine Retention Among Post Recipients. J Clin Nurs 2010; 19: 2771- 6

33. Ringdal $M$, Borg B, Hellström AL. A Survey on Incidence and Factors That May Influence First Postoperative Urination. Urol Nurs 2003; 23 (5): 341-54.

34. Lamonerie L, Marret E, Deleuze A, Lembert N, Dupont
M, Bonnet F. Prevalence of Postoperative Bladder Distension and Urinary Retention Detected by Ultrasound Measurement. BJA 2004; 92(4): 544-6.

35. Hansen BS, Soreıde E, Warland AM, Nilsen OB. Risk Factors of Postoperative Urinary Retention in Hospitalised Patients. Acta Anaesthesiol Scand 2011; 55: 545-8.

36. Orbey BC, Alanoğlu Z, Yılmaz AA, Erkek B, Ates Y, Ayhan Kuzu M. Do We Still Need to Restrict Preoperative Fluid Admnistration in Ambulatory Anorectal Surgery Under Spinal Anaesthesia? Tech Coloproctol 2009; 13: 35-40.

37. Akyolcu N. Ameliyat Sonrası Hemşirelik Bakımı. İçinde Cerrahi Hemşireliği I (Eds Aksoy G, Kanan N, Akyolcu N): 355-6. İstanbul, Nobel Tıp Kitabevleri, 2012.

38. Kulaçoğlu H, Dener C, Kama NA. Urinary Retention After Elective Cholecystectomy. Am J Surg 2001; 182: 226-9.

39. Bjerregaard LS, Bogo S, Raaschou S, Troldborg C, Hornum U, Poulsen AM, et al. Incidence of and Risk Factors for Postoperative Urinary Retention in FastTrack Hip and Knee Arthroplasty. Acta Orthop 2015; 86 (2): 183-8.

40. Eryılmaz $R$, Şahin $M$, Akdağ $M$, Abut $Y$. Inguinal Herni Onarımında Postoperatif Üriner Retansiyon ve Predispozan Faktörler. Ulus Cerrahi Derg 2003; 19(3): 168-72.

41. Verhamme KMC, Sturkenboom MCJM, Stricker BHCh. Drug-induced Urinary Retention. Incidence, Management and Prevention. Drug Saf 2008; 31(5): 373-8. 